\title{
Performance of a variable-rate distribution system for simultaneous fertilizer application
}

\author{
Murilo M. de Barros ${ }^{1}$, Carlos E. S. Volpato², Fabio M. da Silva ${ }^{2}$, \\ Fagner G. da Conceição ${ }^{2}$, Delorme Corrêa Júnior ${ }^{2}$ \& Luiz F. Ribeiro ${ }^{2}$ \\ ${ }^{1}$ Universidade Federal Rural do Rio de Janeiro/Instituto de Tecnologia/Departamento de Engenharia. Seropédica, RJ. E-mail: egmurilo@yahoo.com.br \\ (Corresponding author) \\ ${ }^{2}$ Universidade Federal de Lavras/Departamento de Engenharia. Lavras, MG. E-mail: volpato@deg.ufla.br; famsilva@prpg.ufla.br; desenho.fg@gmail.com; \\ delormeminas@hotmail.com; lf.engagri@gmail.com
}

Key words:

coffee production precision agriculture application at variable doses

\begin{abstract}
A B S T R A C T
The objective of this study was to evaluate the performance of a variable-rate fertilizer distribution system for coffee crop, simultaneously applying two products. Two types of tests were performed: transversal deposition and longitudinal deposition. The transversal deposition test, with tarps, aimed to quantify the variations between programmed and applied doses, using a completely randomized design (CRD), in a factorial scheme, and the Scott-Knott test at $\mathrm{p}<0.05$. The longitudinal deposition test aimed to determine the distribution characteristics of the equipment along the displacement line, based on relative frequency values. In addition, the application rates on both sides of the distribution system were analysed using a CRD and the Scott-Knott test at $\mathrm{p}<0.05$. The application variation in the transversal deposition test with tarps was $1.59 \%$. The variable-rate distribution system remained stable regarding the longitudinal deposition, regardless of any interaction.
\end{abstract}

\section{Palavras-chave:}

cafeicultura

agricultura de precisão

aplicação em doses variáveis

\section{Desempenho de um sistema de distribuição de fertilizantes de aplicação simultânea a taxa variável}

\begin{abstract}
R E S U M O
Objetivou-se, neste trabalho, avaliar o desempenho de um sistema de distribuição de fertilizantes a uma taxa variável para a cultura do café aplicando dois produtos simultaneamente. Realizaram-se dois tipos de ensaio: o de deposição transversal e de deposição longitudinal utilizando-se, nesses ensaios, delineamento inteiramente casualizado (DIC) em esquema fatorial sendo realizado o teste de Scott-Knott a 0,05 de probabilidade. Nos ensaios de deposição transversal objetivou-se quantificar as variações entre as doses programadas e aplicadas enquanto os ensaios de deposição longitudinal tiveram, como objetivo, a determinação das características de distribuição do equipamento ao longo da linha de deslocamento analisados através de valores de frequência relativa; outro fator analisado foi o comportamento de aplicação das doses nos dois lados de distribuição do sistema; observou-se que a variação de aplicação no ensaio de deposição transversal com lonas foi de -1,59\%; o sistema de distribuição a uma taxa variável se manteve estável em relação à deposição longitudinal independente de qualquer interação.
\end{abstract}




\section{INTRODUCTION}

From the $19^{\text {th }}$ century, coffee became the main product in the agro-marketing scene, stimulating Brazilian industrialization in the beginning of the $20^{\text {th }}$ century. Along this course of events, however, Brazilian coffee production has undergone relevant geographical and structural changes and, alternately, moments of crisis, always maintaining its relative importance for the development of the country (Vilela \& Rufino, 2010).

One tool that can be used to increase management capacity is precision agriculture (PA). PA is a form of managing the variabilities from which one intends to benefit, optimizing the use of inputs and reducing costs in favor of the environment and the agricultural production.

According to Bottega et al. (2013), the characterization of the spatial variability of soil chemical and physical attributes through sampling is essential because of its capacity to reduce environmental impacts caused by agricultural practices and optimize the production process. Researches on PA for coffee have shown substantial variability in soil and production attributes.

Silva et al. (2007; 2008) and Ferraz et al. (2012) characterized the spatial variability of soil chemical attributes in the coffee crop and the studied variables showed structure of spatial dependence; these authors also observed that, with great variation amplitude of chemical attributes, the differential and localized application of fertilizers in the coffee crop is justified.

Molin et al. (2010), in a study comparing applications at variable and fixed rates in the coffee crop, observed that the area where the fertilizers were applied in variable rates showed a 34\% yield increase, in comparison to the area under the application of fixed rates. Ferraz et al. (2011) observed that manual application of variable rates of phosphorus and potassium was economically more advantageous, in comparison to the conventional application system.

In order to apply variable doses effectively, fertilizer distribution machines need to be adapted to the characteristics of each crop, since the performance of fertilizer and corrective distributors can be affected by various factors.

Serrano et al. (2007) performed static and dynamic tests using a centrifugal fertilizer distributor for precision agriculture and observed the capacity of the equipment to autoregulate according to the variations in the working velocity and in the applied doses as a function of the georeferenced position in the plots.

Garcia et al. (2012) modeled and simulated the dynamic behavior of an auger-type fertilizer applicator in order to use the variable-rate application and reduce the coefficient of variation (CV) of the application. The model allowed developing strategies for an effective action in order to reduce significantly the $\mathrm{CV}$ of the fertilizer application rate. Thus, there is the need for researches on the development of specific equipment and evaluation parameters for the coffee crop, because, although PA is already a reality in the cultivation of coffee, only a few studies were conducted using machines in this area. Therefore, this study aimed to evaluate the operational performance of a variable-rate fertilizer distribution system, which applies two products simultaneously, and create evaluation parameters for the coffee crop.

\section{Material AND Methods}

Field tests were carried out at the Federal University of Lavras, in Lavras-MG, Brazil ( $21^{\circ} 14^{\prime} \mathrm{S}$; $45^{\circ} 00^{\prime \prime} \mathrm{W}$ ), with mean altitude of $918 \mathrm{~m}$ on a flat surface.

The machine used was a semi-mounted fertilizer distributor, which can apply two types of fertilizers simultaneously, at different rates. The machine is equipped with two independent tracks; two fertilizer tanks, dividing the machine into two equal parts; a volumetric metering mechanism with a variable opening and a centrifugal distributor with two horizontal discs, which direct the application to the planting row through lateral deflectors.

The fertilizer distributor had a load volume of $1.10 \mathrm{~m}^{3}$, i.e., $0.55 \mathrm{~m}^{3}$ for each tank, total width of $1.50 \mathrm{~m}$, length of $3.36 \mathrm{~m}$, height of $1.40 \mathrm{~m}$ and axle track of $1.25 \mathrm{~m}$. In all the tests, the distributor operated with half of its maximum load.

The machine was equipped with an independent power transmission system, composed of a pump, two electrichydraulic flow control valves and two hydraulic motors, which did not require oil flow from the tractor. Through a controller, the system sent signals to the hydraulic valves allowing variation in the flow to the hydraulic motors, leading to the variation in the velocity of the feed track. This variation was based on the fertilizer dose to be applied or the velocity of the motor-mechanical set.

The controller used in the machine had a DGPS receiver with sub-metric accuracy, i.e., with errors of spatial positioning lower than $1.0 \mathrm{~m}$.

The agricultural tractor used was a BX6110 (Agrale), with maximum power of $105 \mathrm{hp}$ and hydraulic system with capacity for maximum pressure of $108 \mathrm{kgf} \mathrm{cm}^{-2}$ and flow rate of $51.5 \mathrm{~L}$ $\mathrm{min}^{-1}$ in the pump of the hydraulic system.

The tests were performed when the wind speed was less than $2 \mathrm{~m} \mathrm{~s}^{-1}$ and the relative air humidity below $80 \%$.

The fertilizers applied in the tests were characterized for granulometry, angle of repose and density. Two commercial fertilizers were used, which are referred to as Product A, with $20 \%$ of $\mathrm{N}$ and $20 \%$ of $\mathrm{K}_{2} \mathrm{O}$ in its formulation, and Product $\mathrm{B}$, with $60 \%$ of $\mathrm{CaO}$ and $30 \%$ of $\mathrm{MgO}$.

For granulometry, $76.41 \%$ of the sample of Product A retained in the mesh showed diameter equal to or higher than $2.8 \mathrm{~mm}$; for Product $\mathrm{B}$, the highest amount of the product retained showed diameter equal to or higher than $4 \mathrm{~mm}$, representing $74.59 \%$ of the sample. Thus, Product B has higher mean diameter of granules in comparison to Product A. The density, humidity and angle of repose of the fertilizers were also analysed. Product A showed density of $1.09 \mathrm{~kg} \mathrm{dm}^{-3}$, humidity of $2.1 \%$ and angle of repose of $25.20^{\circ}$, while Product B showed density of $0.86 \mathrm{~kg} \mathrm{dm}^{-3}$, humidity of $1.8 \%$ and angle of repose of $26.83^{\circ}$.

According to Mialhe (1996), materials with up to $40^{\circ}$ of angle of repose have good flowing characteristics.

Through the transversal deposition test with tarps, two products, three doses and two different velocities were evaluated.

The doses were 400, 700, $1000 \mathrm{~kg} \mathrm{ha}^{-1}$, and the velocities were 4.5 and $6.2 \mathrm{~km} \mathrm{~h}^{-1}$, referring to the B-low $2^{\text {nd }}$ and B-low 
$3^{\text {rd }}$ tractor gears, at motor rotation of 2,200 rpm with power takeoff in the rotation of $540 \mathrm{rpm}$.

A distance of $20 \mathrm{~m}$ between the collecting tarps was adopted for the stabilization of the system and each test had five replicates. After this process, the samples were numbered and weighed on an electronic scale with resolution of $0.01 \mathrm{~g}$.

The test aimed to verify the effects of velocity variations between the programmed and applied doses, besides observing if the precision was altered according to the sides of application in the machine. Ultimately, the material was collected using a pair of 2-m-long tarps covering both distribution sides of the machine.

The difference between programmed and applied doses was evaluated through the percent variation, by collecting all the material deposited on the tarps and extrapolating the values to $\mathrm{kg} \mathrm{ha}{ }^{-1}$.

Based on the variation data, it was evaluated if these errors change depending on the product used, doses, velocities and application side. This analysis was performed using a completely randomized design (CRD), in a $2 \times 3 \times 2$ factorial scheme, with 5 replicates. Significant values were subjected to Scott-Knott test at 0.05 probability level using the computational program Sisvar $^{\circledast}$ (Ferreira, 1999).

The longitudinal deposition test aimed to determine the system's distribution characteristics along the displacement line and verify the doses on both distribution sides.

Trays with dimensions of $0.5 \times 0.5 \mathrm{~m}$ were arranged in single lines, along the machine displacement line, totaling 30 trays on each side. The lines remained $0.7 \mathrm{~m}$ distant from the deflectors of the application system.

Five passings were performed at the doses of 400, 700 and $1000 \mathrm{~kg} \mathrm{ha}^{-1}$, at the velocity of $6.2 \mathrm{~km} \mathrm{~h}^{-1}$ using both products. After application, each sample was numbered and weighed, dividing the obtained value by the number of passings.

With the data obtained by weighing the material, the relative frequency (\%) was calculated based on the highest value obtained (100\%). The data were expressed as Cartesian graph, in which the Y-axis represented the percentage of the applied product in each point along the distance covered in the test.

For the verification of the doses with respect to the variation on both application sides, a CRD was used in a $3 \times 2$ factorial scheme, which consisted of 3 doses and 2 types of fertilizers, with 5 replicates. Significant values were subjected to the ScottKnott test at 0.05 probability level, using the computational program Sisvar $^{\oplus}$ (Ferreira, 1999).

\section{Results AND Discussion}

The analysis of variance for the transversal distribution of the applied product is shown in Table 1.

The interaction of Velocity $\mathrm{x}$ Doses $\mathrm{x}$ Products was not significant ( $p>0.05)$; therefore, the effects of the variations in velocity, doses and products do not interfere with the errors in the application on the right and left sides of the machine.

Thus, regardless of the velocity, application doses and the product used, the system adjusts to the determined conditions and applies the dose required by the controller. Similar result
Table 1. Analysis of variance for the transversal deposition test on both application sides

\begin{tabular}{lccc}
\hline $\begin{array}{c}\text { Sources of } \\
\text { variation }\end{array}$ & DF & \multicolumn{2}{c}{ Mean square and F significance } \\
\cline { 3 - 4 } Product (P) & 1 & Right side error & Left side error \\
\hline Dose (D) & 2 & $0.291099^{\text {ns }}$ & $0.115946^{\text {ns }}$ \\
P x D & 2 & $0.206371^{\text {ns }}$ & $0.415235^{\text {ns }}$ \\
Velocity (V) & 1 & $0.92781^{\text {ns }}$ & $0.027094^{\text {ns }}$ \\
V x P & 1 & $0.513147^{\text {ns }}$ & $0.194019^{\text {ns }}$ \\
V x D & 2 & $0.401484^{\text {ns }}$ & $0.003545^{\text {ns }}$ \\
V x D X P & 2 & $0.275277^{\text {ns }}$ & $1.1744208^{\text {ns }}$ \\
Error & 48 & 0.770544 & 0.735128 \\
CV (\%) & & -52.68 & -57.29 \\
Overall mean & & -1.67 & -1.50 \\
\hline
\end{tabular}

${ }^{n s}$ Not significant; CV - Coefficient of variation; DF - Degrees of freedom

was observed by Umezu \& Capelli (2006), who developed a control mechanism to compensate the change in rotation of fertilizer dosers, at a variable rate, as a function of the change in the temperature of the hydraulic oil.

For all the studied variables, the variable-rate distribution system showed sub-dosage.

The highest and lowest mean errors of application were observed with Product B, which showed variation of $-2.29 \%$ at the velocity of $6.2 \mathrm{~km} \mathrm{~h}^{-1}$ for the dose of $1000 \mathrm{~kg} \mathrm{ha}^{-1}$ and $-0.89 \%$ at the velocity of $4.5 \mathrm{~km} \mathrm{~h}^{-1}$ for the same dose.

The mean value for all the types of variation was $-1.57 \%$. Barros et al. (2015), in a similar study using a variable-rate fertilizer/corrective distribution machine, applying only one product, observed values from -0.74 to $-3.70 \%$ and obtained mean variation of $-2.67 \%$. Thus, the variable-rate distribution system, applying two products simultaneously, can be considered as precise, because, despite having a higher minimum error, the mean of the observed error was lower than the compared value.

This higher precision may be due to the independent hydraulic system, present in the variable-rate application system.

Cerri \& Balastreire (2003) developed a variable-rate fertilizer application system and observed similar and sometimes negative results, around $-0.4 \%$ of error and mean of $0.3 \%$. The data in the present study were very similar to these values, showing that, in general, the system functioned well for the types of fertilizers.

The analysis of variance for longitudinal deposition tests of the applied products is shown in Table 3.

Table 2. Mean error of application (\%) on the right and left sides of a variable-rate fertilizer distribution system using the Products A and B, according to the velocity (V) and the dose (D)

\begin{tabular}{|c|c|c|c|c|}
\hline \multirow{2}{*}{ Product } & \multirow{2}{*}{$V\left(\mathrm{~km} \mathrm{~h}^{-1}\right)$} & \multicolumn{3}{|c|}{ D (kg ha-1) } \\
\hline & & 400 & 700 & 1000 \\
\hline \multicolumn{5}{|c|}{ Right side } \\
\hline \multirow{2}{*}{ A } & 4.5 & -1.55 & -1.64 & -1.50 \\
\hline & 6.2 & -1.69 & -1.40 & -1.80 \\
\hline \multirow{2}{*}{ B } & 4.5 & -1.75 & -1.36 & -1.45 \\
\hline & 6.2 & -1.72 & -1.84 & -2.29 \\
\hline \multicolumn{5}{|c|}{ Left side } \\
\hline \multirow{2}{*}{ A } & 4.5 & -1.75 & -1.21 & -1.20 \\
\hline & 6.2 & -1.38 & -1.49 & -1.69 \\
\hline \multirow{2}{*}{ B } & 4.5 & -1.76 & -1.83 & -0.89 \\
\hline & 6.2 & -1.72 & -0.96 & -2.08 \\
\hline
\end{tabular}


Table 3. Analysis of variance for the longitudinal deposition test with two types of products, for the application doses of 400,700 and $1000 \mathrm{~kg} \mathrm{ha}^{-1}$ considering the right and left sides of the variable-rate distribution system

\begin{tabular}{lcc}
\hline $\begin{array}{c}\text { Source } \\
\text { of variation }\end{array}$ & DF & Mean square and F significance \\
\cline { 3 - 3 } Product (P) & 1 & Deviation in relation to the programmed dose \\
\hline Dose (D) & 2 & $6.1738^{\text {ns }}$ \\
\hline P x D & 2 & $9.6435^{\text {ns }}$ \\
Side (S) & 1 & $3.5515^{\text {ns }}$ \\
S X P & 1 & $2.1921^{\text {ns }}$ \\
S x D & 2 & $4.9721^{\text {ns }}$ \\
S x D x P & 2 & $2.6253^{\text {ns }}$ \\
Error & 24 & $2.5549^{\text {ns }}$ \\
CV (\%) & & 1.6970 \\
Overall mean & & 6.38 \\
\hline
\end{tabular}

${ }^{n s}$ Not significant; CV - Coefficient of variation; DF - Degrees of freedom
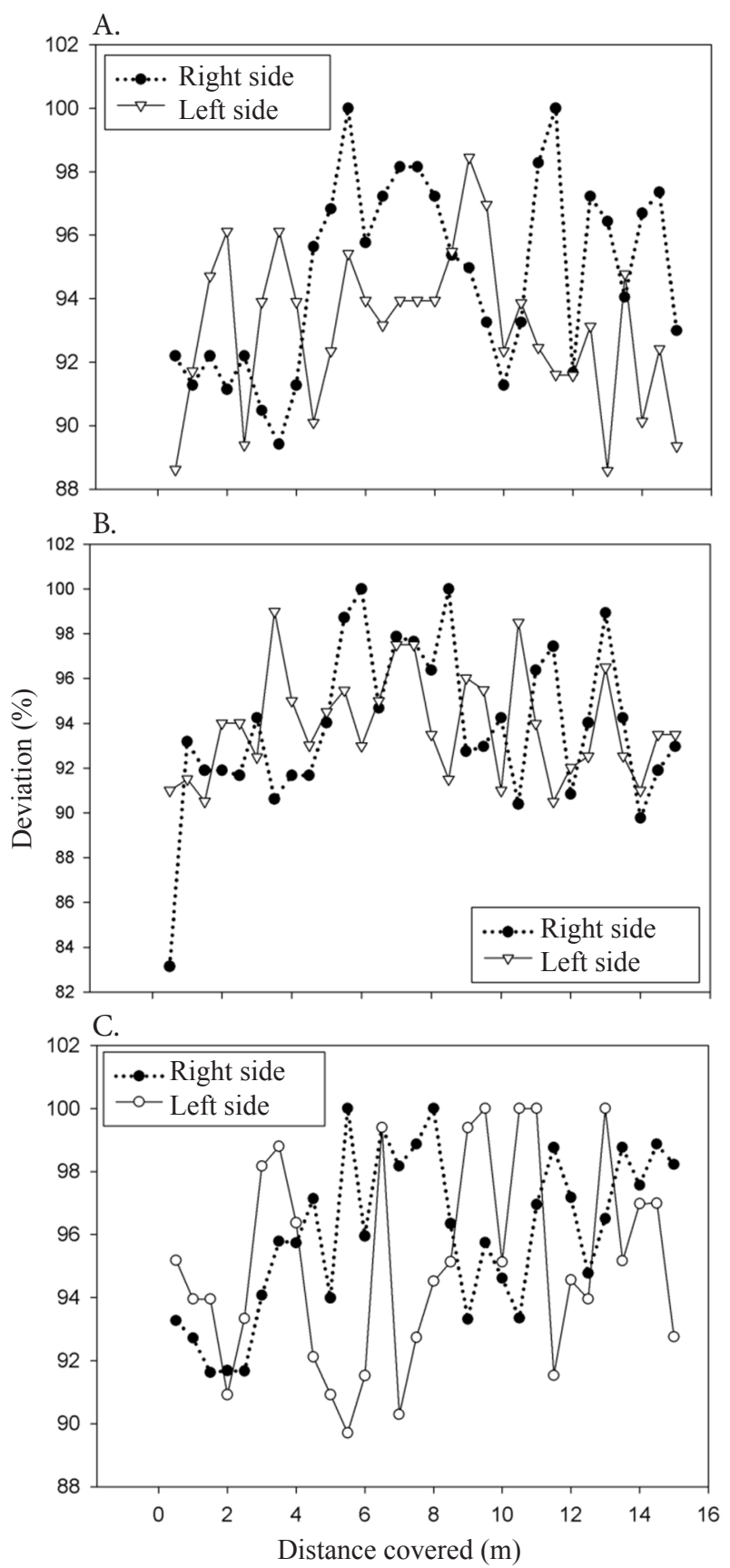

Figure 1. Percent values of longitudinal applications at the doses of $400 \mathrm{~kg} \mathrm{ha}^{-1}(\mathrm{~A}), 700 \mathrm{~kg} \mathrm{ha}^{-1}(\mathrm{~B})$ and $1000 \mathrm{~kg}$ $\mathrm{ha}^{-1}(\mathrm{C})$ for the Product A
None of the interactions showed significant values ( $p$ $>0.05$ ). Thus, regardless of the product, dose or side, the variable-rate distribution system remained stable with respect to longitudinal deposition. Werner et al. (2007), in a similar study but using a one-line applicator with centrifugal distributor, obtained coefficients of variation from 10 to $28 \%$, i.e., much higher than those observed in the present study, which was $6.38 \%$.

Figure 1 represents the variations occurred in the longitudinal application of the Product A, at the doses of 400 (Figure 1A), 700 (Figure 1B) and $1000 \mathrm{~kg} \mathrm{ha}^{-1}$ (Figure 1C).

Figure 2 represents the variations occurred in the longitudinal application of the Product $\mathrm{B}$, at the doses of 400 (Figure 2A), 700 (Figure 2B) and $1000 \mathrm{~kg} \mathrm{ha}^{-1}$ (Figure $2 \mathrm{C})$.
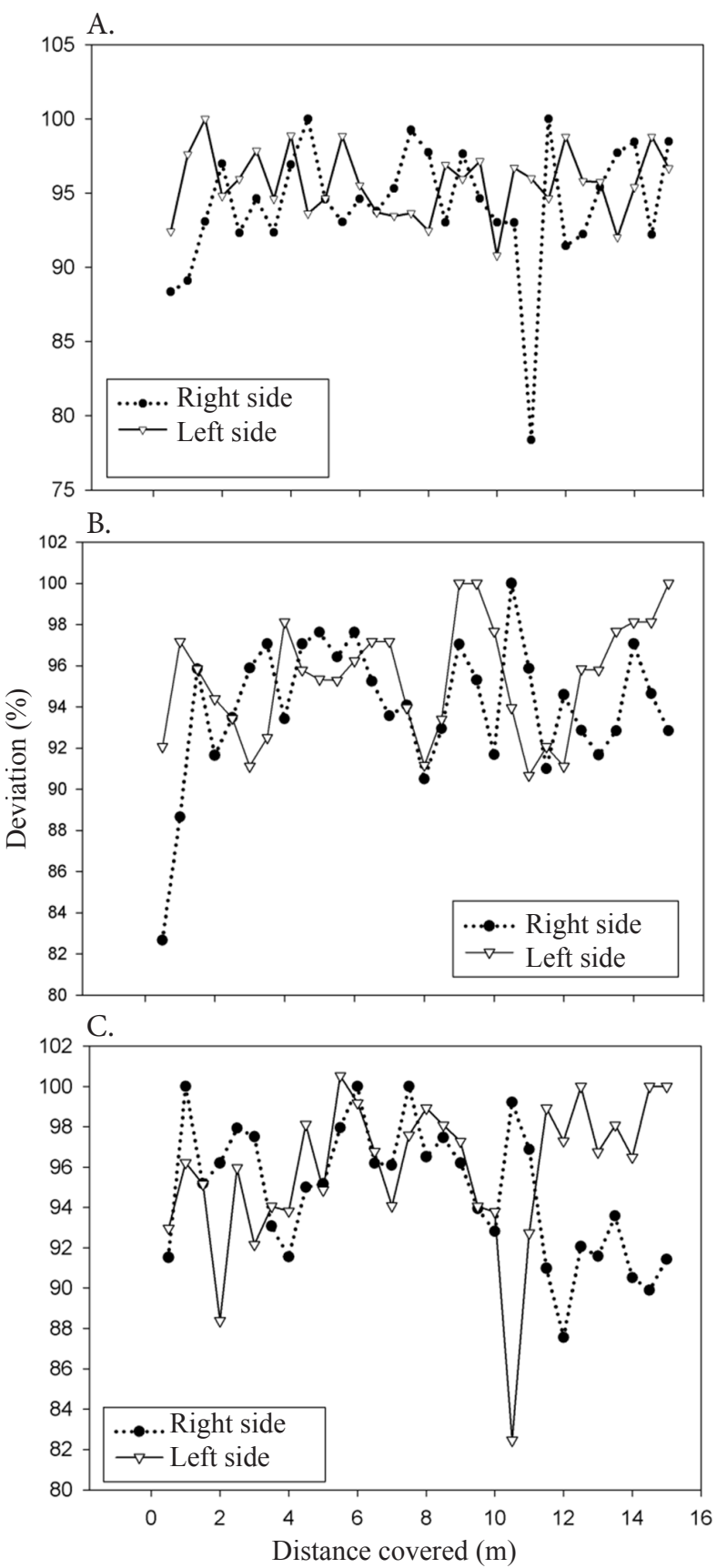

Figure 2. Percent values of longitudinal applications at the doses of $400 \mathrm{~kg} \mathrm{ha}^{-1}(\mathrm{~A}), 700 \mathrm{~kg} \mathrm{ha}^{-1}$ (B) and $1000 \mathrm{~kg}$ $\mathrm{ha}^{-1}(\mathrm{C})$ for the Product B 
As observed in Figures 1 and 2, the variation of the application along the displacement line occurs between the collectors, with values every $0.5 \mathrm{~m}$.

The highest variations occurred at the dose of $400 \mathrm{~kg} \mathrm{ha}^{-1}$ for the Product $B$, which showed higher angle of repose compared with Product A, leading to a more difficult flow of the material in the distribution system (Mialhe, 1996). One factor that can be attributed to these variations is the different densities and particle sizes of the products. Molin et al. (2009) and Werner et al. (2007), in their studies, observed variation in application using centrifugal distribution machines, when the products showed variation in density or particle size. The latter also cites that such deviation or variation can be attributed to the granulometry of the product used, which interferes with its fluidity through the dosing system of the equipment.

\section{Conclusions}

1. Variations of doses, velocities and products did not interfere with the application precision of the system, validating the use of a controller under different field conditions.

2. The mean variation in the application between the programmed and the applied dose for the transversal distribution test with tarps was equal to $-1.57 \%$.

3. The variable-rate distribution system remained stable with respect to the longitudinal deposition, regardless of the variation in the doses, velocities, products and application side, showing maximum mean error of $-7.99 \%$ and minimum of $-3.76 \%$.

\section{ACKNOWLedgments}

To the Federal University of Lavras (UFLA), the Minas Gerais Research Support Foundation (Fapemig) and the National Council for Scientific and Technological Development (CNPq), for the financial support to this research and to the company Belocal, for providing the fertilizers.

\section{Literature Cited}

Barros, M. M.; Volpato, C. E. S.; Silva, F. C.; Palma, M. A. Z.; Spagnolo, R. T. Avaliação de um sistema de aplicação de fertilizantes a taxa variável adaptado à cultura do café. Coffee Science, v.10, p.223633, 2015.

Bottega, E. L.; Queiroz, D. M.; Pinto, F. de A. C.; Souza, C. M. A. Variabilidade espacial de atributos do solo em sistema de semeadura direta com rotação de culturas no cerrado brasileiro. Revista Ciência Agronômica, v.44, p.1-9, 2013. http://dx.doi. org/10.1590/S1806-66902013000100001

Cerri, D. G. P.; Balastrire, L. A. Desenvolvimento de um sistema de aplicação localizada de calcário a taxas variáveis. Engenharia Agrícola, v.23, p.122-128, 2003.
Ferraz, G. A. S.; Silva, F. M.; Carvalho, F. M.; Costa, P. A. N.; Carvalho, L. C. C. Viabilidade econômica do sistema de adubação diferenciado comparado ao sistema de adubação convencional em lavoura cafeeira: Um estudo de caso. Engenharia Agrícola, v.31, p.906-915, 2011.

Ferraz, G. A. S.; Silva, F. M.; Costa, P. A. N.; Silva. A. C.; Carvalho, F. M. Agricultura de precisão no estudo de atributos químicos do solo e da produtividade de lavoura cafeeira. Coffee Science, v.7, p.59-67, 2012.

Ferreira, D. F. Sisivar: Sistema de análise de variância para dados balanceados. Versão 4.0. Lavras: UFLA, 1999.

Garcia, A. P.; Cappelli, N. L.; Umezu, C. K. Auger-type granular fertilizer distributor: matemathical model and dynamic simulation. Revista Engenharia Agrícola, v.32, p.151-163, 2012. http://dx.doi.org/10.1590/S0100-69162012000100016

Mialhe, L. G. Máquinas agrícolas, ensaios \& certificação. São Paulo: Shekinah, 1996. v.1, 722p.

Molin, J. P.; Machado, T. M.; Magalhães, R. P.; Faulin, G. D. C. Segregação de fertilizantes aplicados a lanço. Engenharia Agrícola, v.29, p.614-622, 2009. http://dx.doi.org/10.1590/S010069162009000400011

Molin, J. P.; Montomiya, A. V. A.; Frasson, F. R.; Faulin, G. D. C.; Tosta, W. Test procedure for variable rate fertilizer on coffee. Acta Scientiarum, v.32, p.569-575, 2010. http://dx.doi.org/10.4025/ actasciagron.v32i4.5282

Serrano, J. M.; Peça, M. L. O.; Silva, J. R.; Serrazina, H.; Mendes, J. Avaliação de um distribuidor centrífugo de adubo na perspectiva de utilização em agricultura de precisão. Revista de Ciências Agrárias, v.30, p.79-86, 2007.

Silva, F. M.; Souza, Z. M.; Figueiredo, C. A. P.; Marques Júnior, J.; Machado, R. V. Variabilidade espacial de atributos químicos e de produtividade na cultura do café. Ciência Rural, v.37, p.401407, 2007. http://dx.doi.org/10.1590/S0103-84782007000200016

Silva, F. M.; Souza, Z. M.; Figueiredo, C. A. P.; Vieira, L. H. S.; Oliveira, E. Variabilidade espacial de atributos químicos e produtividade da cultura do café em duas safras agrícolas. Ciência e Agrotecnologia, v.32, p.231-241, 2008. http://dx.doi.org/10.1590/S141370542008000100034

Umezu, C. K.; Cappelli, N. L. Desenvolvimento e avaliação de um controlador eletrônico para equipamentos de aplicação de insumos. Revista Brasileira de Engenharia Agrícola e Ambiental, v.10, p.225-230, 2006. http://dx.doi.org/10.1590/S141543662006000100033

Vilela, P. S.; Rufino, J. L. S. Caracterização da cafeicultura de montanha de Minas Gerais. Belo Horizonte: Instituto Antônio Ernesto de Salvo, 2010. 300p.

Werner, V.; Schlosser, J. F.; Rozin, D.; Pinheiro, E. D.; Dornelles, M. E. C. Aplicação de fertilizantes a taxa variável em agricultura de precisão variando a velocidade de deslocamento. Revista Brasileira de Engenharia Agrícola e Ambiental, v.11, p.658-633, 2007. http:// dx.doi.org/10.1590/S1415-43662007000600016 